\title{
İlkokul Öğretmenlerinin Karşılaştıkları Yıldırma Davranışları ile Motivasyon Düzeyleri Arasındaki İlişki
}

\section{The Relationship between Mobbing Behaviors Primary School Teachers Encountered and Their Motivation}

\author{
Sait AKBAŞLI ${ }^{1}$, Okan DIŞș ${ }^{2}$ Mehmet DURNALI ${ }^{3}$
}

• Geliş Tarihi: 25.07.2019 • Kabul Tarihi: 03.01.2020 • Çevrimiçi Yayın Tarihi: 03.01.2020

\section{Öz}

$\mathrm{Bu}$ araştırma ile ilkokullarda görev yapan öğretmenlerin karşılaştıkları yıldırma davranışları ile motivasyon düzeyleri arasındaki ilişkinin belirlenmesi amaçlanmıştır. Araştırmanın evrenini, 2018-2019 eğitim-öğretim yılında Erzurum ili Yakutiye ilçesinde Milli Eğitim Bakanlığı'na bağlı 59 ilkokulda görev yapan 673 öğretmen oluştururken, örneklemini ise 217 öğretmen oluşturmuştur. Araştırmada veri toplama aracı olarak; araştırmacılar tarafindan geliştirilen Kişisel bilgi formu, Tanhan ve Çam (2011) tarafından geliştirilen "Yıldırma Ölçeği” ve Polat (2010) tarafından geliştirilen “Öğretmen Motivasyonu Ölçeği” kullanılmıştır. Verilerin istatistiksel çözümlemeleri için; ortalama, standart sapma, Pearson Momentler Çarpım Korelasyon Katsayısı kullanılmıştır. Bununla birlikte, bağımsız değişkenlerin bağımlı değişkenleri yordama düzeylerini belirlemek amacıyla Çoklu Doğrusal Regresyon Analizi gerçekleştirilmiştir. Araştırma sonucunda; yıldırma ölçeği boyutları açısından en yüksek düzey mesleki uygulamaların engellenmesi boyutunda tespit edilirken, en düşük düzey ise kişiye yönelik doğrudan hakaret boyutunda tespit edilmiştir. Öğretmen motivasyon ölçeğine ilişkin dağılımlara bakıldığında en yüksek düzey içsel motivasyon boyutunda, en düşük düzey dışsal motivasyon boyutunda olduğu sonucuna ulaşılmıştır. Öğretmenlerin karşılaştıkları yıldırma davranışları ile öğretmenlerin motivasyon düzeyleri arasında anlamlı ilişkiler olduğu tespit edilmiştir. Regresyon analizi sonuçlarına göre, yıldırma ölçeğinin alt boyutlarının, öğretmen motivasyon ölçeğinin alt boyutlarını anlamlı düzeyde yordadığı tespit edilmiştir.

Anahtar sözcükler: Yıldırma davranışı, mobbing, öğretmen motivasyonu, ilkokul, mesleki uygulamaların engellenmesi, dişsal motivasyon

Atıf:

Akbaşl1, S., Diş, O. ve Durnalı, M. (2020). İlkokul öğretmenlerinin karşılaştıkları yıldırma davranışları ile motivasyon düzeyleri arasındaki ilişki. Pamukkale Üniversitesi Eğitim Fakültesi Dergisi, 49, 564581. doi: 10.9779/pauefd.596426

\footnotetext{
${ }^{1}$ Prof. Dr., Hacettepe Üniversitesi, ORCID: 0000-0001-9406-8011, sakbasli@gmail.com

2 Doktora öğrencisi, Hacettepe Üniversitesi, ORCID: 0000-0002-0065-953X, okandis25@gmail.com

${ }^{3}$ Dr. Öğr. Üyesi, Zonguldak Bülent Ecevit Üniversitesi, ORCID: 0000-0002-1318-9362, durnali@gmail.com
} 


\begin{abstract}
The aim of this study was to determine the relationship between the mobbing and motivation levels of the teachers working in primary schools. The population of the study consisted of 673 teachers working in 59 primary schools in Yakutiye district of Erzurum province in 2018-2019 academic year, and 217 teachers were the sample. Personal information form developed by the researchers, "Mobbing Scale" developed by Tanhan and Çam (2011) and "Teacher Motivation Scale" developed by Polat (2010) were used as a data collection tools. Mean, standard deviation, Pearson Product Moment Correlation Coefficient were used for statistical analysis of the data. In addition, Multiple Linear Regression Analysis was performed to determine the predictive levels of independent variables on dependent variables. As a result of the research; in terms of mobbing dimensions, the highest level was determined as the prevention of professional practices and the lowest level was determined as direct insult to the person. Taking the teacher motivation scale into consideration, it was found that the highest level was in intrinsic motivation dimension while the lowest level was in extrinsic motivation dimension. It was determined that there was a significant relationship between mobbing and motivation levels of teachers. According to the results of the regression analysis, it was found that the sub-dimensions of the mobbing significantly predicted the sub-dimensions of the teacher motivation.
\end{abstract}

Keywords: Mobbing, teacher motivation, primary school, prevention of professional practices, external motivation

\title{
Cited:
}

Akbaşl1, S., Diş, O.,\& Durnalı, M. (2020). The relationship between mobbing behaviors primary school teachers encountered and their motivation. Pamukkale Üniversitesi Eğitim Fakültesi Dergisi, 49, 564-581. doi: 10.9779/pauefd.596426. 


\section{Giriş}

Eğitim-öğretim sisteminin temel alt sistemi olarak ilkokullarda hedeflenen başarı, bu örgütlerde görev yapan yönetici ve öğretmenlerin verimli çalışmaları ile ilişkilidir (Ünal, 2000). Verimli çalışabilmenin bir temeli olarak, bu tür örgütlerde çalışanların örgütün amaçlarını gerçekleştirmek istemeleri ve bu amaç doğrultusunda hareket etmeleri önemlidir. Amaçların gerçekleştirilmesinde örgüt üyeleri arasındaki iletişimin önemli bir yeri vardır. Fakat zaman zaman çalışanlar kişisel problemlerinden ötürü sağlıklı bir iletişim kuramayabilirler. Bu durum daha ileri boyutlara taşınarak düşmanlık seviyesine kadar ilerleyebilir. İşte bu noktada, üstten alta, alttan üste ya da yatay olacak şekilde yıldırma davranışları (mobbing) gerçekleşebilir. Mobbing çalışanların psiko-sosyal durumlarını olumsuz etkilediği gibi örgütün amaçlarının gerçekleştirilmesini de zorlaştırabilir. Çeşitli medya organlarında, Türkiye eğitim sisteminin vazgeçilemez öğeleri arasında yer alan öğretmenlerin mobbing davranışlarıyla karşılaştıklarına ilişkin bilgiler yer almaktadır. Örneğin;

Danıştay 2. Dairesi, ders programı haftanın geneline yayılarak zorlaştııldĭ̆g ve ayn gün birkaç okula gidecek şekilde program yapıldığı, birbirine uzak dört okulda birden görevlendirildiği, birbiriyle çakışan görevler verildiği ve bu görevler nedeniyle ruhsal ve psikolojik durumunun bozulduğu sağllk raporuyla belirlenen öğretmenin kendisine mobbing yapıldı̆̆ iddiasıyla açtı̆̆ davada, manevi tazminata ilişkin koşulların oluştuğuna karar verdi (Memurlar.net, 2019).

Mobbing; kişinin bireysel özellikleri fark etmeksizin ortaya çıkan, kişiyi rahatsız etmek amacıyla gerçekleştirilen ve sistematik olarak derinleşen baskıdır. Dolayısıyla mobbing davranışlarına herkes maruz kalabilir. Öyle ki başarılarıyla ön plana çıkan ve yöneticilerin takdirini kazanmış bir çalışan kıskançlık sonucu iftiraya uğrayabilir ve çalışması sabote edilebilir (Mimaroğlu ve Özgen, 2008). Mobbing sürecinin aşamalarından olan psikolojik yıldırma sürecinde, öncelikle bu durumu ortaya çıkaracak bir olayın yaşanması söz konusudur. Devamında ise bireylerin saldırgan davranışlara maruz kalmaları söz konusudur. $\mathrm{Bu}$ durum mobbing davranışlarına maruz kalan kişinin çalışma ortamı ile olumsuz düşüncelere sahip olmasına ve işten ayrılmasına sebep olmaktadır (Leymann, 1996). Bazı durumlarda ise bireyler hatalarını ya da becerisizliklerini kapatmak için mobbingi bir savunma aracı olarak kullanabilirler. Bu nedenle mobbingi net olarak ortaya koymak zorlaşmaktadır. Bir davranışın mobbing olabilmesi için süreklilik arz etmesi ve sistematik olması gerekmektedir. Ayrıca kişinin davranış sonucunda zarar görmesi ve bu durumla baş edemeyecek hale gelmesi gerekmektedir (Erdem, 2014).

Mobbing, örgütte kalıcı sorunlar oluşturan ve örgütün başarı düzeyini olumsuz etkileyen bir olgudur (Tınaz, 2008). Özkul ve Çarıkçı (2010)'ya göre; mobbing, örgüt içinde uyumun bozulması, çalışanların işe yabancılaşması, işten ayrılmaları gibi somut olumsuz sonuçları oluşturabilmektedir. Bu şekilde örgüt nispeten tecrübeli çalışanlarını kaybedebilmekte (Aytaç, 2003) ve çalışanlar açısından örgütsel bağlılı̆̆ın azalmasına yol açabilmektedir (Özkul ve Çarıkçı, 2010). Önlem alınmadığı durumda, mobbing örgütün tamamında etkili olabilir ve örgüt içerisindeki güvenin ortadan kalkmasına sebep olabilir. Ayrıca yöneticiler ve işgörenler birbirlerine uyumsuz davranış sergileyebilir ve sonrasında bu durum performansı düşürebilir (Çobanoğlu, 2005). Diğer bir ifadeyle, örgütün verimsiz olmasının artmasına ve çalışanların motivasyon düzeylerinin azalmasına yol açmaktadır. $\mathrm{Bu}$ durum örgütün varlığını devam ettirmesi açısından olumsuz sonuçlar oluşturur (Davenport, Distler \& Elliott, 2003). 
Mobbing ile ilgili çalışmalar incelendiğinde; mobbing ile iklim ve işten ayrılma niyeti arasında anlamlı ilişki olduğu (Erdirençelebi ve Filizöz, 2016), mobbingin kişilik özellikleri üzerinde etkili olduğu (Glaso, Matthiesen, Nielsen \& Einarsen, 2007), mobbing ile karşı karşıya kalan çalışanların iş performanslarının azaldığı (McKay, Arnold, Fratzl \& Thomas, 2008), öğretmenlerin yıldırma yaşamaları ile örgütsel bağl11ıkları arasında anlamlı ilişki bulunduğu (Ergener, 2008; Mutlu, 2013), mobbing ile iş doyumu arasında anlamlı bir ilişki olduğu (McCormack, Casimir, Djurkovic \& Yang, 2006), okul yöneticilerinin liderlik davranışları sergilemeleri sonucu öğretmenlerin yıldırma yaşama düzeylerinin azaldığı (Elkıran, 2017; Hoel \& Cooper, 2010; Kılınç, 2010; Okçu, 2011) ve mobbing ile örgütsel adanmışlık arasında anlamlı bir ilişki olduğu (Ekinci, 2012) saptanmıştır. Ayrıca, okul yöneticilerince laissez-faire önderlik davranışları gösterildiği oranda öğretmenler üzerindeki yıldırma durumunda artma görüldüğü (Cemaloğlu, 2007), ilkokul ve ortaokullarda görev yapan öğretmenlerce velilere psikolojik yıldırma davranışları gösterilebildiği (Sabancı ve Yücel, 2014) ve öğretmenlerin önyargılarının, örgütsel bağlılık ile psikolojik yıldırma davranışı arasında tamamen aracılık ettiği (Baltacı, 2018), ilköğretim öğretmenlerinin yıldırma davranışları yaşadıkları (Çomak ve Tunç, 2013), öğretmenlerin çoğunun yıldırma davranışıyla karşılaştıkları ve sebebinin en çok denetim ve görmezden gelinme olduğu (Nanto ve Özan, 2016), öğretmenlerin mobbing alg1 düzeyleri yükseldikçe, örgütsel adalet algılarını düşmekte, örgütsel sessizlik düzeyler yükselmekte olduğu (Güngör ve Potuk, 2018) ve demokratik liderlik ile öğretmenlerin karşılaştıkları yıldırma davranışları arasındaki ilişki negatif iken otokratik liderlik ile pozitif olarak (Peker, İnandı ve Gılıç, 2018) saptanmıştır. Literatürün bu noktasında, ilkokullarda görev yapan öğretmenlerin karşılaştıkları yıldırma davranışları ile ilişkili bir diğer önemli konu olarak öğretmenlerin motivasyonu ele alınabilir.

Motivasyon temel anlamda bir insanın hangi işi yapmaktan daha çok haz almasıyla ilgili bir konudur (Dogani, 2010). Motivasyon, insan davranışlarını yönlendiren ve sürekliliği sağlayan önemli bir parametre olarak ele alınmaktadır (Wright \& Wiediger, 2007). Motivasyon bireyleri harekete geçiren ve bireylerin hareketlerinin yönlerini belirleyen düşünceler, umutlar, inançlar, ihtiyaçlar ve korkulardır (Eren, 2008). Psiko-sosyal bir canlı olan insan somut ya da gözle görülmeyen soyut birtakım ihtiyaçlara sahiptir. Kişinin bu ihtiyaçlarının giderilmesi, performansı üzerinde etkili olmaktadır (Fındıkçı, 2009). Aslında motivasyon, istek ve hevesle yaptığımız işlerle ilgili olarak hissettiğimiz duygulardır (Bentley, 2000). Dolayısıyla motivasyon, objektif bir durum olmayan, bireyin davranışlarının gözlenerek anlaşılabilen kişisel bir meseledir. Motivasyon bireyi istekli bir şekilde çalışmaya ve başarmaya teşvik eden bir güçtür (Bayraktar, 2015). Motive olmuş bireylerin hedefler doğrultusunda hareket etmeleri ve bu hedefleri gerçekleştirme düzeylerinin yüksek olduğu söylenebilir (Jonett, 2009).

Motivasyon sayesinde örgüt çalışanlarının çabalarını hedefler doğrultusunda yoğunlaştırmak mümkündür. Örgüt elemanlarının yaptıkları işi benimsemeleri, istekli olmaları ve yeterince gayret göstermeleri motivasyon düzeylerine bağlıdır (Fındıkç1, 2009). Bu temelde, örgütlerin çalışanları güdüleme biçimleri; örgütün yönetim anlayışına, içinde bulunduğu çevreye ve kültürel değerlere göre farklılık gösterebilir. Çalışanları motive etmek için tek bir yol yoktur. Ortaya konulacak motive etme tekniğinin çalışanlar için uygun olmasına dikkat edilmelidir. Bir örgüt çalışanı için uygun olan bir teknik başka bir çalışan için anlamlı olmayabilir. Bu durumda çalışanın motive edilmesi söz konusu değildir (Ergül, 2005). Çalışanları örgüt yararına harekete geçirmek için motive etmek ve onları uzun vadede işte tutmak oldukça zor bir durumdur. Çalışanların verimli olarak çalışmaya sevk edecek, sorumluluk almalarını sağlayacak, 
problemleri çözmeleri için harekete geçirecek ve başarılarını ödüllendirecek bir ortamın oluşturulması, yapılması gereken işlerin başında gelir (Öztürk ve Dündar, 2003). Dolayısıyla çalışanların, ihtiyaçlarının karşılandığı etkili bir yönetime ihtiyacı bulunmaktadır. Yöneticilerin, çalışanların ihtiyaçlarını karşılama düzeyleri onların örgüte olan bağlılıklarını etkileyecektir. Örgütle özdeşleşen çalışanlar daha verimli ve etkili olacaktır. Böyle bir bağlanma, örgütün amaçlarını gerçekleşmesi, yaşamını sürdürmesi için temel gerekliliktir. Bu durumu göz önünde bulunduran yöneticiler hem çalışanların ihtiyaçlarının giderilmesini hem de örgütün amaçlarına ulaşmasını sağlayacaktır (Ergül, 2005). Bu bağlamda, yöneticilerin örgüt çalışanlarını motive etmede dikkat etmesi gereken hususlardan bazıları şu şekilde sıralanabilir (Dogani, 2010):

- Yönetim bilincine sahip bir yönetici çalışanlarını iyi bir şekilde tanımalı ve ihtiyaçlarını bu doğrultuda belirlenmelidir.

- Çalışanlarını motive etmek için çeşitli ödüllerin olabileceğini düşünmelidir. Çalışanların ihtiyaçları göz önünde bulundurularak çeşitli ödüller kullanılmalıdır.

- Hedefler örgüt çalışanları ile birlikte belirlenmeli, karar sürecine katılım sağlanmalıdır. Çalışanların yetenekleri doğrultusunda gerçekçi hedefler ortaya konulmalıdır. Yönetici hedeflerin gerçekleştirilmesi sürecinde ise yönlendirici olmalıdır.

- Çalışanların başarılı çalışmaları övgüyle ve ödülle pekiştirilmelidir.

- Gücü çalışanlar için bir baskı aracı olarak kullanmamalıdır.

Motivasyon konusuyla ilgili gerçekleştirilen araştırmalar incelendiğinde; okul yöneticilerinin sosyal iletişim becerileri ile öğretmenlerin motivasyon düzeyleri arasında anlamlı ilişki olduğu (Bektaş, 2010; Doğan ve Koçak, 2014), yöneticilerin liderlik davranışlarının öğretmenlerin motivasyonlarını etkilediği (Aksel, 2016; Arslanoğlu, 2016; Bankowski, 2002; Bryant, 1996; Emirbey, 2017; Ergen, 2009; Everett, 1988; Pennington, 1997; Smith, 1999; Sucu, 2016), öğretmenlerin motivasyon düzeyleri ile iş tatmini arasında ilişki olduğu (Davis \& Wilson, 2000; Maharjan, 2012), motivasyonel faktörlerinin örgütsel vatandaşl1k üzerinde belirleyici olduğu (Köprülü, 2011), öğretmen motivasyonu ile yönetici tutumları arasında anlamlı ilişki bulunduğu (Çalış, 2012), öğretmenlerin mobbing yaşama düzeyleri ile motivasyon arasında anlamlı ilişki olduğu (Avc1, 2015), öğretmenlerin örgütsel bağl1lıkları ile motivasyon arasında anlamlı ilişki bulunduğu (Bang, Rose \& Reio, 2013; Kalay, 2015), örgüt kültürü ile motivasyon arasında anlamlı ilişki olduğu (Bilegt, 2012), okul müdürünün kullandığı motivasyon sağlamaya yönelik dilin öğretmenin okul müdürüne duyduğu bağlılığı anlamlı olarak yordadığı (Demir, 2019), öğretmenlerin dijital teknolojilere erişim motivasyonunun önemli olduğu (Erçetin, Akbaşlı ve Durnalı, 2018) ve okul müdürlerinin motivasyon etkinliklerini çoğunlukla gerçekleştirdiği (Ünal, 2000) görülmektedir.

Öğretmenlerin yıldırma davranışları ile karşılaştıklarında motivasyonunun ne düzeyde etkileneceğinin bilinmesi okul örgüt üyelerinin birbirlerine karşı daha dikkatli ve özenli davranmalarına katkı sağlayabilir. Bu durum okul paydaşlarının kendilerini yaptıkları işe vermeleri ve görevlerini istekli bir biçimde icra etmeleri açısından önemlidir. Bu araştırma bu bağlamda önemlidir ve literatürde mevcut benzer konularda gerçekleştirilen araştırma bulgu ve sonuçlarını destekleme veya eleştirme noktasında farklı bilgiler sunarak literatüre katkı sunma potansiyeline sahiptir. Araştırmacılardan biri sınıf öğretmeni olarak görev yaptı̆̆ i için örneklemi oluşturan sınıf öğretmenlerine daha kolay ulaşılabilmiştir. Ayrıca, eğitim sisteminin ana öğeleri arasında yer alan öğretmenler içerisinde sınıf öğretmenlerinin okul örgütünde öğrenciyle ve 
okul yöneticileriyle daha çok etkileşim halinde olduğu düşünüldüğünden örneklemin ilkokul öğretmenlerinden seçilmesine karar verilmiştir. Araştırma sonuçları, ilkokullarda öğretmenlerin karşılaştıkları yıldırma davranışları ve öğretmenlerin motivasyon düzeyleri hakkında bilgi vermektedir.

$\mathrm{Bu}$ araştırma ile ilkokullarda görev yapan öğretmen görüşlerine göre, aşağıdaki problem durumları çözümlenmiştir:

1) Öğretmenlerin görüşlerine göre, öğretmenlerin karşılaştıkları yıldırma davranışları ve motivasyon düzeyleri nasıldır?

2) Öğretmenlerin görüşlerine göre, öğretmenlerin karşılaştıkları yıldırma davranışları ve motivasyon düzeyleri arasında anlamlı ilişki var mıdır?

3) Öğretmenlerin görüşlerine göre, öğretmenlerin karşılaştıkları yıldırma davranışları, ögretmenlerin motivasyon düzeylerini anlamlı düzeyde yordamakta mıdır?

\section{Yöntem}

İlişkisel tarama modeli (Mertens, 2010) ile desenlenen bu betimsel araştırmada; ilkokul öğretmenlerinin görüşlerine göre, okul yöneticilerinin öğretmenler üzerinde sergilediği mobbing davranışları ile öğretmenlerin motivasyon düzeyleri arasındaki ilişkiler incelenmiştir. Ayrıca, okul yöneticilerinin öğretmenler üzerinde sergilediği mobbing davranışlarının öğretmenlerin motivasyon düzeyleri yordama düzeyleri de incelenmiştir. Araştırmanın bağımlı değişkenlerini motivasyon ölçeğinin; iç motivasyon ve dış motivasyon alt boyutları oluşturmaktadır. Bağımsız değişkenler ise, yıldırma ölçeğinin; mesleki uygulamaların engellenmesi, potansiyelin engellenmesi, kişinin itibarına saldırılar, kişiye yönelik doğrudan hakaret ve sosyal ilişkilerin engellenmesi alt boyutlarıdır.

\section{Çalışma Grubu}

Araştırmanın evrenini 2018-2019 eğitim öğretim yılında Erzurum ili Yakutiye ilçesinde Milli Eğitim Bakanlığına bağlı 59 ilkokulda görev yapan 673 öğretmen oluşturmuştur. Araştırmanın örneklemini ise, basit tesadüfi örneklem yöntemi ile belirlenen 217 öğretmen oluşturmuştur. Örneklem büyüklüğü, \%95'lik güven düzeyi ve \%5'lik sapma miktarı için esas alındığında 673 olan öğretmen evrenini 217 öğretmenin temsil edebileceği belirlenmiştir (Yazıcıoğlu ve Erdoğan, 2004). Örneklem grubunu oluşturan öğretmenlerin \%53'ünü kadın öğretmenler; \%47'sini erkek öğretmenler oluşturmaktadır. Öğretmenlerin mesleki kıdem değişkenine göre \%12'sinin 1-5 yıllık, \%18.4'ünün 6-10 yıllık, \%25.8'inin 11-15 y1llık, \%24.4'ünün 16-20 y1llık, \%19.4'ünün 21 yıl ve üzeri kıdeme sahip oldukları tespit edilmiştir.

\section{Çalışmada Kullanılan Ölçme Araçları}

Veri toplamak amacıyla; araştırmacılar tarafından geliştirilen Kişisel bilgi formu, Tanhan ve Çam (2011) tarafından geliştirilen "Yıldırma Ölçeği” ve Polat (2010) tarafından geliştirilen “Öğretmen Motivasyonu Ölçeği” kullanılmıştır.

Kişisel Bilgi Formu: Örnekleme katılan öğretmenlerin cinsiyet ve kıdem değişkenlerinin belirlenmesinde kişisel bilgi formu kullanılmıştır. 
Yıldırma Ölçeği: Ölçek 29 madde ve beş alt boyuttan oluşmaktadır. Beşli Likert tipinde derecelendirilen ölçek, (5) Her Zaman, (4) Sıklıkla, (3) Bazen, (2) Nadiren ve (1) Asla seçenekleri bulunmaktadır. Orijinal ölçeğin, Cronbach Alpha değeri ölçek bütünü için 0.92; "Mesleki Uygulamaların Engellenmesi" boyutu için 0.82, "Potansiyelin Engellenmesi" boyutu için 0.85, "Kişinin İtibarına Saldırılar" boyutu için 0.70, "Kişiye Yönelik Doğrudan Hakaret" boyutu için 0.61 ve "Sosyal İlişkilerin Engellenmesi" boyutu için 0.53 olarak hesaplanmıştır. Bu araştırma için gerçekleştirilen güvenirlik analiz sonuçlarına göre; Cronbach Alpha iç tutarlılık katsayısı ölçek bütünü için .96; "Mesleki Uygulamaların Engellenmesi" boyutu için .93; "Potansiyelin Engellenmesi" boyutu için .91; "Kişinin İtibarına Saldırılar" boyutu için .86; "Kişiye Yönelik Doğrudan Hakaret" boyutu için .67 ve "Sosyal İlişkilerin Engellenmesi" boyutu için .87 olarak bulunmuştur. Doğrulayıcı Faktör Analizi (DFA) sonucunda ölçeğin beş faktörlü yapısına ilişkin modelin verilerle uyum gösterdiği anlaşılmıştır $(\mathrm{x} 2 / \mathrm{sd}=1.95$; RMSEA $=.05 ; \mathrm{CFI}=.97$; GFI $=.95$ ). Ölçekte yer alan maddelere örnek olarak "Gözümü korkutmak amacıyla şiddet gösterilerinde bulunuluyor." ve "Öğrencilerimin karşısında eleştiriliyorum." verilebilir.

Öğretmen Motivasyon Ölçeği: Ölçek 24 madde ve iki alt boyuttan oluşmaktadır. Beşli Likert tipinde derecelendirilen ölçek, (5) Her Zaman, (4) Sıklıkla, (3) Bazen, (2) Nadiren ve (1) Asla seçenekleri bulunmaktadır. Orijinal ölçeğin, Cronbach Alpha değeri ölçek bütünü için 0.92; "Dışsal Motivasyon" boyutu için 0.87, "İçsel Motivasyon" boyutu için 0.88 olarak hesaplanmıştır. $\mathrm{Bu}$ araştırma için gerçekleştirilen güvenirlik analiz sonuçlarına göre ölçeğin Cronbach Alpha iç tutarlı1ık katsayısı ölçek bütünü için .97; "İçsel Motivasyon” boyutu için .93 ve "Dişsal Motivasyon" boyutu için .90 olarak bulunmuştur. DFA sonucunda ölçeğin iki faktörlü yapısına ilişkin modelin verilerle uyum gösterdiği anlaşılmıştır (x2/sd = 1.84; RMSEA $=.05 ; \mathrm{CFI}=.95 ; \mathrm{GFI}=.97)$. Ölçekte yer alan maddelere örnek olarak "Yaptığım işten aldığım ücretin miktarı beni tatmin ediyor." ve "Yaptığım işle ilgili konularda karar verebilmem beni mutlu ediyor." verilebilir.

\section{Verilerin Analizi}

Veri analizi temel olarak iki aşamada gerçekleştirilmiştir. Birinci aşamada, bilgisayar ortamına aktarılan veriler eksik ya da hatalı değer uç değerler açısından incelenmiş, ikinci aşamada ise araştırmanın alt problemleri çözümlenmiştir. Hatalı değer analizinde, yanlışlıkla hatalı girildiği düşünülen değerler düzeltilmiştir. Bağımsız değişkenler arasında çoklu bağlantı probleminin olup olmadığına yönelik yapılan analiz sonucunda, VIF değerlerinin 10'dan ve CI değerlerinin de 30'dan küçük olduğu, otokorelasyon için Durbin Watson değerlerinin 1.50 ile 2.10 aralığında olduğu, tolerans değerlerinin .10'un üzerinde olduğu, Skewness and Kurtosis katsayıs1 değerlerinin -1.5 ile 1.5 arasında olduğu görülmüş ve elde edilen bu sonuçlardan hareketle çoklu bağlantı probleminin olmadığına karar verilmiştir. Öncelikle, alt problemler temelinde her bir alt boyutta yer alan bütün maddelerin aritmetik ortalama puanları hesaplanmıştır. Pearson Momentler Çarpım Korelasyon Katsayısı (r) kullanılarak ilişkiler hesaplanmıştır. Ayrıca, Çoklu Doğrusal Regresyon Analizi gerçekleştirilerek bağımsız değişkenlerin bağımlı değişkenleri yordama düzeylerini belirlenmiş̧tir. Standartlaştırılmış Beta $(\beta)$ katsayıları ve t-testi sonuçları dikkate alınarak Regresyon analizleri yorumlanmıştır. 0.05 anlamlılık düzeyi temel alınmıştır.

\section{Bulgular}

$\mathrm{Bu}$ bölümde araştırma alt problem cümlecikleri temelinde elde edilen bulgular ve yorumlara yer verilmiştir. 


\section{Öğretmenlerin Karşılaştıkları Yıldırma Davranışlarına İlişkin Görüşleri}

Öğretmenlerin, karşılaştıkları yıldırma davranışlarına ilişkin görüş düzeyleri Tablo 1'de yer almaktadir.

Tablo 1. Yıldırma davranışları alt boyutlarına ilişkin aritmetik ortalama ve standart sapma değerleri $(\mathrm{N}=\mathbf{2 1 7})$

\begin{tabular}{lcc}
\hline Alt Boyutlar & $\bar{X}$ & Ss \\
\hline 1. Mesleki Uygulamaların Engellenmesi & 2.49 & 1.03 \\
2. Potansiyelin Engellenmesi & 2.25 & 1.04 \\
3. Kişinin İtibarına Saldırılar & 2.12 & .98 \\
4. Kişiye Yönelik Doğrudan Hakaret & 1.82 & .71 \\
5. Sosyal İlişkilerin Engellenmesi & 2.20 & 1.14 \\
\hline$* * p<.01$ & &
\end{tabular}

Öğretmenlerin görüşlerine göre, yıldırma davranışlarına ilişkin dağılımlar incelendiğinde; en yüksek ortalama mesleki uygulamaların engellenmesi boyutunda ( $\bar{X}=2.49)$ olurken, en düşük ortalamanın kişiye yönelik doğrudan hakaret boyutunda $(\bar{X}=1.82)$ olduğu görülmektedir. Yıldırma davranışlarına yönelik diğer dağılımlara bakıldığında ise boyutlara ait ortalamaların, potansiyelin engellenmesi boyutunda $(\bar{X}=2.25)$, kişinin itibarına saldırılar boyutunda $(\bar{X}=2.12)$ ve sosyal ilişkilerin engellenmesi boyutunda $(\bar{X}=2.20)$ olduğu görülmektedir.

\section{Öğretmenlerin Motivasyona İlişkin Görüşleri}

Öğretmenlerin motivasyona ilişkin görüş düzeyleri bulguları Tablo 2'de yer almaktadır.

Tablo 2. Motivasyon alt boyutlarına ilişkin aritmetik ortalama ve standart sapma değerleri ( $\mathbf{N}=\mathbf{2 1 7})$

\begin{tabular}{lcc}
\hline Alt Boyutlar & $\bar{X}$ & $S s$ \\
\hline 1. İç Motivasyon & 3.34 & .97 \\
2. Diş Motivasyon & 3.25 & 1.08 \\
\hline$* * p<.01$ & &
\end{tabular}

Öğretmenlerin görüşlerine göre, motivasyona ilişkin dağılımlar incelendiğinde; en yüksek ortalamanın içsel motivasyon boyutunda $(\bar{X}=3.34)$, en düşük ortalamanın ise dışsal motivasyon boyutunda ( $\bar{X}=3.25)$ olduğu görülmektedir.

\section{Yıldırma Davranışları ile Motivasyon Boyutları Arasındaki Korelasyonlar}

Araştırmanın bağımlı ve bağımsız değişkenleri arasındaki korelasyon katsayıları Tablo 3'te verilmiştir.

Tablo 3 incelendiğinde öğretmenlerin karşılaştıkları yıldırma davranışları ile motivasyon düzeyleri arasında anlamlı ilişkilerin olduğu görülmektedir. Yıldırma ölçeğinin mesleki uygulamaların engellenmesi ile öğretmen motivasyon ölçeğinin içsel motivasyon ( $r=-$ $.95, p<.01)$ ve dişsal motivasyon $(r=-.93, p<.01)$ boyutları arasında negatif yönde ve yüksek düzeyde anlamlı bir ilişki olduğu görülmektedir. Yıldırma ölçeğinin potansiyelin engellenmesi ile öğretmen motivasyon ölçeğinin içsel motivasyon $(r=-.93, p<.01)$ ve dişsal motivasyon $(r=-$ $.94, p<.01)$ boyutları arasında negatif yönde ve yüksek düzeyde anlamlı bir ilişki olduğu görülmektedir. Bununla birlikte yıldırma ölçeğinin kişinin itibarına saldırılar ile öğretmen motivasyon ölçeğinin içsel motivasyon $(r=-.92, p<.01)$ ve dişsal motivasyon $(r=-.91, p<.01)$ boyutları arasında negatif yönde ve yüksek düzeyde anlamlı bir ilişki olduğu görülmektedir. 
Ayrıca yıldırma ölçeğinin kişiye yönelik doğrudan hakaret ile öğretmen motivasyon ölçeğinin içsel motivasyon $(r=-.78, p<.01)$ ve dişsal motivasyon $(r=-.80, p<.01)$ boyutları arasında negatif yönde ve yüksek düzeyde anlamlı bir ilişki olduğu görülmektedir. Son olarak yıldırma ölçeğinin sosyal ilişkilerin engellenmesi ile öğretmen motivasyon ölçeğinin içsel motivasyon $(r=-.90, p<.01)$ ve dışsal motivasyon $(r=-.91, p<.01)$ boyutları arasında negatif yönde ve yüksek düzeyde anlamlı bir ilişki olduğu görülmektedir.

Tablo 3. Yıldırma Davranışları ve Motivasyon Arasındaki Korelasyonlar ( $\mathbf{N}=\mathbf{2 1 7})$

\begin{tabular}{lccccccc}
\hline Alt Boyutlar & 1 & 2 & 3 & 4 & 5 & 6 & 7 \\
\hline 1.MeslekiUygulamaların Engellenmesi & - & & & & & & \\
2.Potansiyelin Engellenmesi & $.94^{* *}$ & - & & & & & \\
3.Kişinin İtibarına Saldırılar & $.92^{* *}$ & $.91^{* *}$ & - & & & & \\
4.Kişiye Yönelik Doğrudan Hakaret & $.79^{* *}$ & $.79^{* *}$ & $.79^{* *}$ & - & & & \\
5.Sosyal İlişkilerin Engellenmesi & $.89^{* *}$ & $.89^{* *}$ & $.86^{* *}$ & $.74^{* *}$ & - & & \\
6.İçsel Motivasyon & $-.95^{* *}$ & $-.93^{* *}$ & $-.92^{* *}$ & $-.78^{* *}$ & $-.90^{* *}$ & - & \\
7.Dışal Motivasyon & $-.93^{* *}$ & $-.94^{* *}$ & $-.91^{* *}$ & $-.80^{* *}$ & $-.91^{* *}$ & $.94^{* *}$ & - \\
\hline$* * p<.01$ & & & & & & &
\end{tabular}

Yıldırma Davranışlarının Motivasyon Boyutlarını Yordama Düzeyi

Öğretmenlerin karşılaştıkları yıldırma davranışları ile öğretmen motivasyonu arasında çoklu regresyon analizi gerçekleştirilerek, sonuçlar Tablo 4 ve Tablo 5 'te verilmiştir.

\section{İcsel Motivasyon Boyutunun Yordanmast}

İçsel motivasyon boyutunun yordanmasına ilişkin çoklu doğrusal regresyon analizi sonuçları Tablo 4'te verilmiştir.

Tablo 4. İçsel Motivasyon Boyutunun Yordanmasına İlişsin Çoklu Doğrusal Regresyon Analizi Sonuçları

\begin{tabular}{lccccc}
\hline Alt Boyutlar & $B$ & $S h$ & $\beta$ & $t$ & $P$ \\
\hline Sabit & 5.388 & .048 & - & 111.230 & $.000^{*}$ \\
1.Mesleki Uygulamaların Engellenmesi & -.401 & .059 & -.455 & -6.831 & $.000^{*}$ \\
2.Potansiyelin Engellenmesi & -.129 & .055 & -.147 & -2.352 & $.020^{*}$ \\
3.Kişinin İtibarına Saldırılar & -.176 & .047 & -.190 & -3.729 & $.000^{*}$ \\
4.Kişiye Yönelik Doğrudan Hakaret & -.046 & .039 & -.036 & -1.168 & .244 \\
5.Sosyal İlişkilerin Engellenmesi & -.137 & .034 & -.173 & -4.033 & $.000^{*}$ \\
\hline$F=57.025 ; p<.05 R=.96 ; R^{2}=.93$ & & & & &
\end{tabular}

Tablo 4'te görüldüğü gibi, yıldırma ölçeğinin; mesleki uygulamaların engellenmesi, potansiyelin engellenmesi, kişinin itibarına saldırılar, kişiye yönelik doğrudan hakaret ve sosyal ilişkilerin engellenmesi boyutları, öğretmen motivasyon ölçeğinin içsel motivasyon boyutunu yordama gücü istatistiksel olarak anlamlı bulunmuştur $(F=57.025, p<.01)$. Bu yordayıc1 değişkenler, içsel motivasyon boyutu puanındaki değişimin \%93'ünü $\left(R=.96, R^{2}=.93\right)$ açıklayabilmektedir. Yıldırma ölçeğinin; mesleki uygulamaların engellenmesi $(\beta=-.455, p<.05)$, potansiyelin engellenmesi $(\beta=-.147, p<.05)$, kişinin itibarına saldırılar $(\beta=-.190, p<.05)$ ve sosyal ilişkilerin engellenmesi $(\beta=-.173, p<.05)$ boyutları içsel motivasyon boyutunu negatif yönde ve anlamlı düzeyde yordamaktadır. Yıldırma ölçeğinin; kişiye yönelik doğrudan hakaret $(\beta=-.036, p<.05)$ boyutu içsel motivasyon boyutunun tek başına anlamlı yordayıcısı değildir. Standardize edilmiş regresyon katsayısına göre $(\beta)$ yordayıcı değişkenlerin içsel motivasyon 
boyutu üzerindeki göreli önem sırasının; kişiye yönelik doğrudan hakaret, potansiyelin engellenmesi, sosyal ilişkilerin engellenmesi, kişinin itibarına saldırılar ve mesleki uygulamaların engellenmesi olduğu görülmektedir.

\section{Dışsal Motivasyon Boyutunun Yordanması}

Dışsal motivasyon boyutunun yordanmasına ilişkin çoklu doğrusal regresyon analizi sonuçları Tablo 5'te verilmiştir.

Tablo 5. Dışsal Motivasyon Boyutunun Yordanmasına İlişskin Çoklu Doğrusal Regresyon Analizi Sonuçları

\begin{tabular}{lccccc}
\hline Değişken & $B$ & $S h$ & $\beta$ & $t$ & $P$ \\
\hline Sabit & 5.313 & .052 & - & 102.089 & $.000^{*}$ \\
1.Mesleki Uygulamaların Engellenmesi & -.201 & .063 & -.222 & -3.189 & $.002^{*}$ \\
2.Potansiyelin Engellenmesi & -.291 & .059 & -.323 & -4.954 & $.000^{*}$ \\
3.Kişinin İtibarına Saldırılar & -.146 & .051 & -.153 & -2.878 & $.004^{*}$ \\
4.Kişiye Yönelik Doğrudan Hakaret & -.098 & .042 & -.074 & -2.319 & $.021^{*}$ \\
5.Sosyal İlişkilerin Engellenmesi & -.192 & .036 & -.235 & -5.261 & $.000^{*}$ \\
\hline$F=52.924 ;{ }^{*} p<.05 R=.90 ; R^{2}=.92$ & & & & &
\end{tabular}

Tablo 5'te görüldüğg̈ gibi, yıldırma ölçeğinin; mesleki uygulamaların engellenmesi, potansiyelin engellenmesi, kişinin itibarına saldırılar, kişiye yönelik doğrudan hakaret ve sosyal ilişkilerin engellenmesi boyutları, öğretmen motivasyon ölçeğinin dışsal motivasyon boyutunu yordama gücü istatistiksel olarak anlamlı bulunmuştur $(F=52.924, p<.01)$. Bu yordayıc1 değişkenler, dışsal motivasyon boyutu puanındaki değişimin \%92'sini $\left(R=.90, R^{2}=.92\right)$ açıklayabilmektedir. Yıldırma ölçeğinin; mesleki uygulamaların engellenmesi $(\beta=-.222, p<.05)$, potansiyelin engellenmesi $(\beta=-.323, p<.05)$, kişinin itibarına saldırılar $(\beta=-.153, p<.05)$, kişiye yönelik doğrudan hakaret $(\beta=-.074, p<.05)$ ve sosyal ilişkilerin engellenmesi $(\beta=-.235, p<.05)$ boyutları dışsal motivasyon boyutunu negatif yönde ve anlamlı düzeyde yordamaktadır. Standardize edilmiş regresyon katsayısına göre $(\beta)$ yordayıcı değişkenlerin dışsal motivasyon boyutu üzerindeki göreli önem sırasının; kişiye yönelik doğrudan hakaret, kişinin itibarına saldırılar, mesleki uygulamaların engellenmesi, sosyal ilişkilerin engellenmesi ve potansiyelin engellenmesi olduğu görülmektedir.

\section{Tartışma ve Sonuç}

$\mathrm{Bu}$ araştırmada öğretmenlerin karşılaştıkları yıldırma davranışları ile öğretmenlerin motivasyon düzeyleri arasındaki ilişki incelenmiştir. Araştırmada; yıldırma davranışları alt boyutları açısından en yüksek ortalama mesleki uygulamaların engellenmesi boyutunda olurken, en düşük ortalamanın ise kişiye yönelik doğrudan hakaret boyutunda olduğu tespit edilmiştir. Öğretmenlerin mesleki gelişimlerinin engellendiği, öğretmenlerin mesleki gelişimlerine yönelik isteklerinin geri çevrildiği ya da dikkate alınmadığı söylenebilir. Ayrıca, öğretmenlerin mesleki yeterliklerinin küçümsendiği ve yaptıkları başarılı işlerin dahi önemsenmediği ifade edilebilir. Öğretmen motivasyonuna ilişkin dağılımlara bakıldığında içsel motivasyon boyutunda ortalamanın yüksek, dışsal motivasyon boyutunda ise düşük olduğu tespit edilmiştir. Öğretmenler yaptıkları işin değerli olduğunu düşünmektedirler. Öğretmenlerin yaptıkları işte kendilerini başarılı gördükleri ve işlerini isteyerek yaptıkları söylenebilir. Böyle bir durumda öğretmenler kendilerini görev yaptıkları okulun önemli bir parçası olarak görebilir. Karcıŏlu ve Çelik (2012), Şahin ve Dündar (2011), Polat (2010), İren (2015) ve Aksel (2016) tarafından 
gerçekleştirilen araştırmalarda benzer sonuçlar elde edilmiştir. Eğitim sisteminin verimliliğinin artırılmasında motivasyonun önemli bir etkisi vardır (Chen, 2001; Evans, 2000). Bireylerin sorumlu oldukları görevlerde başarılı olmaları yaptıkları işi sevmelerine bağlıdır. Kişi sevdiği işi yaptığında mutlu olur ve bu durum verimliliğin artmasına katkı sağlar. Burada ise yöneticilerin de etkisi olduğu unutulmamalıdır. İçsel motivasyon ile birlikte dışsal motivasyonda oldukça etkilidir. Bireydeki takdir edilme duygusu onların dışsal güdülenme düzeylerinin artırılmasında oldukça önemlidir. Okul yöneticisi bu durumu avantaja çevirmeli ve öğretmenleri amaçlar doğrultusunda harekete geçirebilmelidir (Bentley, 1999). Eğer bir işgören işi ile özdeşleşmiş ise, işi ile ilgili sorun ortaya çıktığında da, tıpkı kendi kişisel sorunuymuş gibi doğal olarak bu sorunları çözmeye güdülenir. Bu yüzden işi ile özdeşleşmiş olan işgörenlerin sorunu çözmeyi yüklenmesi kendiliğinden oluşacağından, yöneticinin bu işgörenleri motive etmesi kolaylaşır (Başaran, 1982).

Öğretmenlerin karşılaştıkları yıldırma davranışları ile öğretmen motivasyon düzeyleri arasında anlamlı ilişkilerin olduğu görülmektedir. Yıldırma ölçeğinin mesleki uygulamaların engellenmesi, potansiyelin engellenmesi, kişinin itibarına saldırılar, kişiye yönelik doğrudan hakaret ve sosyal ilişkilerin engellenmesi alt boyutları ile öğretmen motivasyon ölçeğinin içsel motivasyon ve dışsal motivasyon alt boyutları arasında negatif yönde ve yüksek düzeyde anlamlı bir ilişki olduğu görülmektedir. McKay, Arnold, Fratzl \& Thomas (2008), McCormack, Casimir, Djurkovic \& Yang (2006) yaptıkları araştırmalarda benzer sonuçlara ulaşmışlardır. Bu ilişkiler temelinde, öğretmenlerin okulda karşılaştıkları yıldırma davranışları onların yaptıkları işi benimsemelerine engel olabilir. İşini benimsemeyen, yaptığ 1 işten haz almayan kişilerin başarıya ulaşmaları çok zordur. Görev yaptığı kuruma isteyerek gitmeyen, yapılacak etkinliklere katılmak istemeyen, okulun hedeflerini benimsemeyen ve bu doğrultuda hareket etmeyen öğretmenlerin örgütsel hedefleri gerçekleştirme düzeylerinde düşüş yaşanabilir. Yıldırma davranışları ile karşı karşıya kalan öğretmenlerin kendilerini okulun bir parçası olarak görmeleri neredeyse mümkün değildir. Hatta ilk firsatta farklı bir okula gitme arzusuyla çalıştıkları okulu değiştirme eğiliminde olabilirler. Kendilerini okuldan izole eden öğretmenlerin okulda etkin olmalarını, kendilerini okula ve öğrencilerine adamalarını beklememek gerekir. Dolayısıyla öğretmenlerin sağlıklı bir ortamda çalışmalarını sağlayacak olumlu bir havanın oluşturulması gerekmektedir. Örgütlerde başarıyı elde etmek için karşılıklı etkileşime ihtiyaç vardır. Her yönetici çalışanlarına bağımlıdır ve onları etkileyemezse zor durumda kalırlar (Hanks, 1999). İyi bir yönetici, kişiliğinden doğan otoritenin ve her şeyden çok insan ilişkilerindeki yeteneğinin, pozisyon ve statüsünden kaynaklanan resmi gücüne kıyasla çok üstün olduğunu bilir (Hagemann, 1997). Motivasyon ile performans arasında doğru orantı vardır. Motivasyon ne kadar yüksekse, performans da o derece yüksek olur. Ancak burada kişinin bilgi, beceri, eğitim ve diğer yetenekleriyle beraber çevresel faktörlerin de yeterli düzeyde olması gerekir (Bayraktar, 2015). Okul yöneticileri güçlerini öğretmenleri motive etmek için kullanabilecekleri gibi, öğretmenler üzerinde bir baskı aracı olarak da kullanabilirler. Bu baskı sürekli hale gelir ve çalışanları rahatsız edecek düzeye ulaşır ise yıldırma davranışının ortaya çıktığı söylenebilir. Günel'e (2010) göre İş yaşamında mobbing'e maruz kalan çalışanlar fiziksel ve psikolojik rahatsızlıklar yaşamaktadırlar. Bunun sonucunda da, iş yerindeki verimlilik ve etkinlikleri azalmakta, işe devamsızlıkta ve iş devir oranında artış olmaktadır. Mobbing okulun iklimini de olumsuz etkileyerek diğer çalışanlarında söz konusu durumdan etkilenmelerine sebep olabilir. Öğretmen ve yöneticiler arasında yaşanan yıldırma davranışları diğer öğretmenlerinde ikirciklik yaşamasına yol açabilir. Böylece sağlıklı bir iletişimin kurulması ve çalışanlar arasında eş güdümün sağlanmasının zorlaşması beklenir. Erdem'e (2014) göre; yıldırma davranışları örgütte 
yıldırma davranışlarına maruz kalanların yanında, bu durumu gözlemleyenlerin de rahatsızlığına, stres yaşamalarına sebep olabilir. İş görenlerin iş huzuru sorunu oluşabilecektir. İş görenler, örgüt ile olan bağlantının zedelendiğini hissedecektir. Örgüt tamamen olumsuz ve mutsuz bir ortam olabilecektir.

Regresyon analizi sonuçları incelendiğinde, yıldırma davranışlarının; mesleki uygulamaların engellenmesi, potansiyelin engellenmesi, kişinin itibarına saldırılar ve sosyal ilişkilerin engellenmesi boyutları içsel motivasyon boyutunu negatif yönde ve anlamlı düzeyde yordamaktadır. Yıldırma davranışlarının; mesleki uygulamaların engellenmesi, potansiyelin engellenmesi, kişinin itibarına saldırılar, kişiye yönelik doğrudan hakaret ve sosyal ilişkilerin engellenmesi boyutları dışsal motivasyon boyutunu negatif yönde ve anlamlı düzeyde yordamaktadır. Öğretmenlerin yıldırma davranışlarına maruz kalmaları sonucu motivasyon düzeylerinin düştüğü görülmektedir. Bir birey olan öğretmen aynı zamanda sosyal bir varlıktır. $\mathrm{Bu}$ nedenle birtakım ihtiyaçları bulunmaktadır. Bu ihtiyaçlardan biri de görev yaptığı okulda çalışma arkadaşları ve okul yönetimi ile etkili bir iletişime geçebilmektir. İhtiyaçların karşılanması öğretmenlerin motive olmalarında önemli bir etkendir. Öğretmenler üzerinde bask1 oluşturmak onların içindeki çalışma azmini ortadan kaldırabilir.

Eğitim örgütlerinde örgüt üyeleri arasında gerçekleşen 'samimi' insan ilişkilerine dayalı iletişim önemlidir. $\mathrm{Bu}$ bağlamda, okul yöneticilerinin bu konuda kendilerini geliştirmeleri ve geliştirmelerini sağlayabilir politika ve uygulamaların üst düzey eğitim yöneticilerince sağlanması beklenir. Bu durumun bir sonucu olarak, örgütün amaçlarının üst düzeyde gerçekleştirilmesi noktasında, öğretmenlere karşı sergileyebilecekleri yıldırma davranışlarının körelmesi gerçekleşebilir. Ayrıca, öğretmenleri motive olmalarına yardımcı olabilir motivasyon araç ve kaynaklarını yöneticilerin kullanabilmeleri beklenir. Örneğin, gerçekleştirilen çalışmalar karşısında öğretmenlere teşekkür etmek dahi etkili olacaktır. Bu durum öğretmenlerin dikkate alındığının ve onlara değer verildiğinin bir göstergesi olabilir. Öğretmenler arasında iş bölümü yapılırken iş yükünün adaletli dağıtımına dikkat edilmesi gerekmektedir. İş bölümü yapılırken öğretmenlerin alanlarının ve yeteneklerinin göz önünde bulundurulması gerekir. Okul yöneticisinin öğretmenler arasında adaleti sağlaması önem arz etmektedir. Okul yöneticisinin öğretmenlere karşı adaletli davranmaları öğretmenlerin yöneticilere karşı güven duygusunun gelişmesinde etkili olabilir. Okul yöneticileri ve öğretmenler kendi aralarında etkili bir iletişime geçmeleri samimi bir okul ortamının oluşmasını kolaylaştırabilir. Eğitim örgütlerinde çatışma yaşanması olası bir durumdur. Okul yöneticileri çatışma ortamından faydalanmayı ve dezavantaj gibi görünen bu durumu örgütün gelişimi açısından avantaja dönüştürmeyi bilmelidir. Yaşanan aksaklıklar, problemler çözülemeyecek hale gelmeden, sorunlar yumağı olmadan mantıklı çözüm önerileri ortaya konulabilir.

İlkokul Öğretmenlerinin Karşılaştıkları Yıldırma Davranışları ile Motivasyon Düzeyleri Arasındaki İlişki başlıklı çalışmanın yazım sürecinde bilimsel, etik ve alıntı kurallarına uyulmuş; toplanan veriler üzerinde herhangi bir tahrifat yapılmamış, karşılaşılacak tüm etik ihlallerde "Pamukkale Üniversitesi Eğitim Fakültesi Dergisi Yayın Kurulunun" hiçbir sorumluluğunun olmadığı, tüm sorumluluğun Sorumlu Yazara ait olduğu ve bu çalışmanın herhangi başka bir akademik yayın ortamına değerlendirme için gönderilmemiş olduğunu taahhüt ederim. 


\section{Kaynakça}

Aksel, N. (2016). Ortaokul müdürlerinin dönüşümcü liderlik davranışları ile öğretmenlerin motivasyonu arasındaki ilişki (Samsun ili örneği). Yayımlanmamış yüksek lisans tezi, Ondokuz Mayıs Üniversitesi, Eğitim Bilimleri Enstitüsü, Samsun.

Arslanoğlu, Ş. (2016). Lise müdürlerinde liderlik, liderlik düzeylerinin öğretmenlerin motivasyonuna etkisi (Konya ili örneği). Yayımlanmamış yüksek lisans tezi, KTO Karatay Üniversitesi, Sosyal Bilimler Enstitüsü, Konya.

Avc1, L. (2015). Öğretmenlerin yıldırma (mobing) yaşama düzeyleri ile motivasyon düzeyleri arasındaki ilişkinin incelenmesi (Düzce ili örneği). Yayımlanmamış yüksek lisans tezi, Yeditepe Üniversitesi, Eğitim Bilimleri Enstitüsü, İstanbul.

Aytaç, S. (2003). Çalışma psikolojisi alanında yeni bir yaklaşım: Örgütsel sağlık. Endüstri İlişkileri ve Insan Kaynaklarl Elektronik Dergisi,5(2), 10-18.

Baltacı, A. (2018). Psikolojik Yıldırma ve Örgütsel Bağlılık İlişkisinde Önyargının Aracılık Rolü. Bilecik Şeyh Edebali Üniversitesi Sosyal Bilimler Enstitüsü Dergisi, 3(1), 141-161. doi: 10.33905/bseusbed.411725

Bang, H., Ross, S. and Reio, T. G. (2013). From motivation to organizational commitment of volunteers in non-profit sport organizations. The role of job satisfaction. Journal of Management Development, 32(1), 96-112.

Bankowski, B. (2002). A study of the relationship between transformational leadership and teacher motivation in New York City Elementary Schools, Ph.D. Dissertation. St. John's University Faculty of the School of Education, New York.

Başaran, İ.E. (1982). Örgütsel davranış. Ankara: Ankara Üniversitesi Eğitim Fakültesi Yayınları.

Bayraktar, H. V. (2015). Sınıf yönetiminde öğrenci motivasyonu ve motivasyonu etkileyen etmenler. Electronic Turkish Studies, 10(3), 1079-1100.

Bektaş, A. (2010). İlköğretim okulu yöneticilerinin sosyal iletişim becerileri ile sınıf öğretmenlerinin motivasyonu arasındaki ilişki. Yayımlanmamış yüksek lisans tezi, Gazi Üniversitesi, Eğitim Bilimleri Enstitüsü, Ankara.

Bentley, T. (1999). Insanları motive etme. (Çev: O. Yıldırım). İstanbul: Hayat Yayınları.

Bentley, T. (2000). Takımınızın yeteneklerini geliştirmede insanlar motive etme. İstanbul: Hayat Yayınları.

Bilegt, E. (2012). Örgüt kültürü ile çalışan motivasyonu arasındaki ilişki ve bir araştırma. Yayınlanmamış yüksek lisans tezi, İstanbul Üniversitesi, Sosyal Bilimler Enstitüsü, İstanbul.

Bryant, R. L. (1996). The relationship between leadership styles of public secondary school principals and the motivation levels of their teachers. Doctoral dissertation, Wayne State University Faculty of the Graduate School, Michigan.

Cemaloğlu, N. (2007). Okul yöneticilerinin liderlik stilleri ile yıldırma arasındaki ilişki. Hacettepe Üniversitesi Eğitim Fakültesi Dergisi,33(33), 77-87, Retrieved from http://dergipark.org.tr/hunefd/issue/7805/102342

Chen, A. (2001). A theoretical conceptualization formotivation research in physicaleducation: An integrated perspective, Quest, 2, 35-58.

Çalış, H. (2012). Öğretmen motivasyonunda yönetici yaklaşımlarının incelenmesi (Kocaeli ili Gölcük ilçesi örneği). Yayımlanmamış yüksek lisans tezi, Yeditepe Üniversitesi, Sosyal Bilimler Enstitüsü, İstanbul.

Çobanoğlu, Ş. (2005). Mobbing-işyerinde duygusal saldırı ve mücadele yöntemleri. İstanbul: Timaş Yayınları.

Çomak, E., ve Tunç, B. (2013). İlköğretim Öğretmenlerinin İlköğretim Okullarında Yaşadıkları Yıldırma Durumlar1. Mersin Üniversitesi Eğitim Fakültesi Dergisi, 8(3), 197-208. Retrieved from http://dergipark.org.tr/mersinefd/issue/17381/181558

Davenport, N. Distler, R. S. \& Elliott, G. P. (2003). Mobbing, işyerinde duygusal taciz. (Çev: Osman C. Önertoy). İstanbul: Sistem Yayıncılık. 
Davis, J. \& Wilson, S. M. (2000). Principals' efforts to empower teachers: Effects on teacher motivation and job satisfaction and stress. The Clearing House: A Journal of Educational Strategies, Issues and Ideas, 73(6), 349-353.

Demir, S. (2019). Okul müdürünün kullandığı motivasyonel dil ile öğretmenin müdüre duyduğu bağl111k arasındaki ilişki. Pamukkale Üniversitesi Eğitim Fakültesi Dergisi, 46, 365-379. doi:10.9779/pauefd.47360

Dogani, O. (2010). Yönetim bilinci ve motivasyon. İstanbul: Karma Yayıncılık.

Doğan, S. ve Koçak, O. (2014). Okul yöneticilerinin sosyal iletişim becerileri ile öğretmenlerin motivasyon düzeyleri arasındaki ilişki. Kuram ve Uygulamada Eğitim Yönetimi, 20(2), 191-216.

Ekinci, Ö. (2012). Ortä̈gretim okulu ögretmenlerinin mobbing ile örgütsel adanmışlıkları arasındaki ilişki. Yayımlanmamış yüksek lisans tezi, Necmettin Erbakan Üniversitesi, Eğitim Bilimleri Enstitüsü, Konya.

Elkıran, M. E. (2017). Akademisyenlerin algıladıkları yıldırma (mobbing) davranışları ile yöneticilerin liderlik davranışları arasındaki ilişki. Yayımlanmamış yüksek lisans tezi, Çanakkale Onsekiz Mart Üniversitesi, Eğitim Bilimleri Enstitüsü, Çanakkale.

Emirbey, A. R. (2017). Okul yöneticilerinin etik liderlik davranışları ile öğretmen motivasyonu arasındaki iliş̧ki (Denizli ili Çivril ilçe örneği). Yayımlanmamış yüksek lisans tezi, Uşak Üniversitesi, Sosyal Bilimler Enstitüsü, Uşak.

Erçetin, Ş. Ş., Akbaşl1, S. ve Durnalı, M. (2018). Dijital Teknolojilere Erişim Motivasyonu Ölçeğinin Türkçe'ye uyarlanmasi: Geçerlik ve güvenirlik çalişmasi. Sakarya University Journal of Education, 8(4), 75-88. doi: 10.19126/suje.431126

Erdem, T. (2014). Mobbing ve mobbing ile mücadele yöntemleri. Türk Kütüphaneciliği Dergisi, 28(4), 622-628.

Erdirençelebi, M. ve Filizöz, B. (2016). Yıldırma Davranışlarının etik iklim ve çalışanların işten ayrılma niyeti üzerine etkileri. Selçuk Üniversitesi Sosyal Bilimler Enstitüsü Dergisi, 35, 127-139.

Ergen, Y. (2009). İlköğretim okulu müdürlerinin öğretim liderlik davranışlarının öğretmenlerin motivasyonu üzerindeki etkisi (Manisa ili örneği). Yayımlanmamış yüksek lisans tezi, Celal Bayar Üniversitesi, Sosyal Bilimler Enstitüsü, Manisa.

Ergener, B. (2008). İlköğretim okullarında görev yapan öğretmenlerin yıldırma yaşamaları ile örgütsel bağlllıkları arasındaki ilişski. Yayımlanmamış yüksek lisans tezi, Gazi Üniversitesi, Eğitim Bilimleri Enstitüsü, Ankara.

Ergül, H. F. (2005). Motivasyon ve motivasyon teknikleri. Elektronik Sosyal Bilimler Dergisi 4(4), 67-79.

Evans, L. (2000). The effects of educational change on moral, job satisfaction and motivation. Journal of Educational Change, 1, 173-192.

Everett, G. B. (1988). A study of the relationship between principal's leadership style and the level of motivation of the teaching staff. Doctoral dissertation, Tennessee State University Graduate School, Tennessee.

Fındıkçı, İ. (1999). İnsan kaynakları yönetimi. İstanbul: Alfa Yayıncılık.

Glaso, L., Matthiesen, S.B., Nielsen M.B. \& Einarsen, S. (2007). Do targets of workplace bullying portray a general victim personality profile? Scandinavian Journal of Psychology, 48, 313-319.

Günel, Ö.D. (2010). İşletmelerde yıldırma olgusu ve yıldırma mağdurlarının kişilik özelliklerine ilişkin bir araştırma. Dokuz Eylül Üniversitesi Sosyal Bilimler Enstitüsü Dergisi, 12(3), 37-65.

Güngör, S. K., \& Potuk, A. (2018). Öğretmenlerin mobbing, örgütsel adalet ve örgütsel sessizlik algıları ve aralarındaki ilişki. Hacettepe Üniversitesi Eğitim Fakültesi Dergisi, 33(3), 723-742.

Hagemann, G. (1997). The motivation manual. (2. Baskı). (Çev. G. Aksan). İstanbul: Rota Yayıncılık.

Hanks, K. (1999). Motivating people. (Çev. C. İkizler). İstanbul: Alfa Yayıncılık.

Hoel, H. \& Cooper, C. L. (2010) Leadership styles as predictors of self-reported and observed workplace bullying, British Journal of Management, 21(2), 453-468.

İren, S. (2015). İlkokullarda görev yapan ögretmenlerin örgütsel adalet algllarl ile mesleki motivasyon düzeyleri arasındaki ilişkinin incelenmesi: Tuzla örneği. Yayımlanmamış yüksek lisans tezi, İstanbul Aydın Üniversitesi, Sosyal Bilimler Enstitüsü, İstanbul. 
Jonett, J. L. F. (2009). The motivation of teachers to assume the role of cooperating teacher. Unpublished doctoral dissertation, Cardinal Stritch Universty.

Kalay, M. (2015). Illkokul ve ortaokullarda görev yapan öğretmenlerin örgütsel bağlllık ve motivasyonları arasındaki ilişsk (Bolu ili örneği). Yayımlanmamış yüksek lisans tezi, Abant İzzet Baysal Üniversitesi, Eğitim Bilimleri Enstitüsü, Bolu.

Karcığlu, F., ve Çelik, Ü. H., (2012). Mobbing (Yıldırma) ve örgütsel bağlılığa etkisi, Atatürk Üniversitesi, IIBF Dergisi, 26(1), 59-75.

Kılınç, A. Ç. (2010). Okul yöneticilerinin etik liderlik davranışları gösterme düzeyleri ile öğretmenlerin yaşadıkları örgütsel güven ve yıldırma arasındaki ilişski. Yayımlanmamış yüksek lisans tezi, Gazi Üniversitesi, Eğitim Bilimleri Enstitüsü, Ankara.

Köprülü, T. S. (2011). İlköğretim okullarındaki ögretmenlerin örgütsel vatandaşlık davranışları ile motivasyonları arasındaki ilişki. Yayımlanmamış yüksek lisans tezi, Maltepe Üniversitesi, Sosyal Bilimler Enstitüsü, İstanbul.

Leymann, H. (1996). The content and development of mobbing at work. European Journal of Work and Organizational Psychology, 5(2), 165- 184.

Maharjan, S. (2012). Association between work motivation and job satisfaction of college teachers. Administrative and Management Review, 24(2), 45-55.

McCormack, D., Casimir, G., Djurkovic, N. \& Yang, L. (2006). The concurrant effects of workplace bullying, satisfaction with supervisor, and satisfaction with co-workers on affective commitment among schoolteachers in China. International Journal of Conflict Management, 17(4), 316-331.

McKay, R., Arnold, D. H., Fratzl, J., \& Thomas, R. (2008). Workplace bullying in academia:

Canadian study. Employee Responsibilities and Rights Journal, 20(2), 77-100.

Memurlar.net (2019). Öğretmene mobbingle ilgili önemli Danıştay kararl. Retreived from https://www.memurlar.net/haber/805188/ogretmene-mobbingle-ilgili-onemli-danistaykarari.html

Mertens, D. M. (2014). Research and evaluation in education and psychology: Integrating diversity with quantitative, qualitative, and mixed methods. California: Sage Publications.

Mimaroğlu, H. ve Özgen, H. (2008). Örgütlerde güncel bir sorun: "Mobbing". Sosyal Ekonomik Araştırmalar Dergisi, 8(15), 201-226.

Mutlu, N. (2013). Öğretmenlere göre psikolojik ylldırmanın örgütsel bağlllık üzerindeki etkisi. Yayımlanmamış yüksek lisans tezi, Pamukkale Üniversitesi, Eğitim Bilimleri Enstitüsü, Denizli.

Nanto, Z., ve Özan, M. (2016). Öğretmenlerin Yaşadıkları Yıldırma Durumlarının İncelenmesi. Uşak Üniversitesi Eğitim Araştırmaları Dergisi, 2(3), 112-128. doi: 10.29065/usakead.256382

Okçu, V. (2011). Okul yöneticilerinin liderlik stilleri ile öğretmenlerin örgütsel bağlllıkları ve yıldırma yaşama düzeyleri arasındaki ilişkilerin incelenmesi. Yayımlanmamış doktora tezi, Gazi Üniversitesi, Eğitim Bilimleri Enstitüsü, Ankara.

Özkul, B. ve Çarıkçı, İ. H. (2010). Mobbing ve Türk hukuku açısından değerlendirilmesi. Süleyman Demirel Üniversitesi İktisadi ve İdari Bilimler Fakültesi Dergisi, 15(1), 481-499.

Öztürk, Z. ve Dündar, H. (2003). Örgütsel motivasyon ve kamu çalışanlarını motive eden faktörler. C.Ü. İktisadi ve İdari Bilimler Dergisi, 4(2), 57-67.

Peker, S., İnandı, Y., \& Gılıç, F. (2018). The relationship between leadership styles (autocratic and democratic) of school administrators and the mobbing teachers suffer. European Journal of Contemporary Education. 7(1), 150-164, doi: 10.13187/ejced.2018.1.150

Pennington, P. W. (1997). Principal leadership and teacher motivation in secondary schools. Doctoral dissertation, Tennessee State University Graduate School, Tennessee.

Polat, S. (2010). Okul öncesi yöneticilerinin kullandıklarl yönetsel gü̧ kaynaklarına ilişkin öğretmen algıları ile öğretmen motivasyonu arasındaki ilişki. Yayımlanmamış yüksek lisans tezi, Yeditepe Üniversitesi, Sosyal Bilimler Enstitüsü, İstanbul.

Sabancı, A., ve Yücel, E. (2014). İlk ve ortaokul öğretmenlerinin velilere yönelik psikolojik yıldırma davranışları gösterme düzeyi. Turkish Journal of Education, 3(3), 40-55. doi: 10.19128/turje. 181086 
Smith, T. M. (1999). A study of the relationship between principal's leadership style and teacher motivation: the teachers' perspective. Doctoral dissertation, Georgia State University College of Education, Georgia.

Sucu, A. (2016). Öğretmenlerin motivasyonu ile okul yöneticilerinin öğretimsel liderlik davranışları arasındaki ilişkinin analizi. Yayımlanmamış yüksek lisans tezi, İnönü Üniversitesi, Eğitim Bilimleri Enstitüsü, Malatya.

Şahin, B. ve Dündar, T. (2011). Sağlık çalışanlarının yıldırma (mobbing) davranışlarıyla karşılaşma düzeylerini etkileyen faktörlerin incelenmesi: Bolu ili örneği, Tisk Akademi, 2(12), 88-117.

Tanhan, F. ve Çam, Z. (2011). Öğretmenlere yönelik yıldırma ölçeğinin geçerlik ve güvenirliğinin yeniden belirlenmesi, Çukurova Üniversitesi Eğitim Fakültesi Dergisi,1(40), 80-97.

Tınaz, P. (2008) İş yer inde psikolojik taciz (Mobbing) Beta yayınları, İstanbul.

Ünal, S. (2000). İlköğretim Okulu Yöneticilerinin Okullarında Motivasyonu Sağlama Etkinlikleri. Pamukkale Üniversitesi Eğitim Fakültesi Dergisi, 7 (7), 84-90. Retrieved from http://dergipark.org.tr/pauefd/issue/11136/133208

Wright, J., \& Wiediger, R. (2007). Motivated behaviours: The interaction of attention, habituation and memory. In L. Brown (Ed.), Psychology of motivation (pp. 5-28). New York, USA: Nova Science Publishers Inc.

Yazıcıoğlu, Y. ve Erdoğan, S. (2004). SPSS uygulamalı bilimsel araştırma yöntemleri. Ankara: Detay Yayıncillk. 


\section{Extended Abstract}

\section{Introduction}

The achievement of primary education in primary schools as the basic sub-system of the education system is related to the productive and collaborative work of the administrators and teachers working in these organizations (Ünal, 2000). As a basis for working efficiently, it is important that employees in such organizations want to achieve the objectives of the organization and act accordingly. Communication among the members of the organization has an important role in achieving the objectives. However, from time to time, employees may not be able to establish healthy communication due to personal problems. This situation can result in the next level of hostility. At this point, mobbing may be seen from top to bottom, bottom to top or horizontal. Mobbing negatively affects the psychosocial status of employees and may make it difficult to realize the goals of the organization.

Mobbing is a phenomenon that creates permanent problems in the organization and adversely affects the success level of the organization (Tinaz, 2008). According to Özkul and Çarıç̧ (2010); mobbing can create concrete negative results such as deterioration of the harmony within the organization, alienation of employees to work. In this way, the organization may lose relatively experienced employees (Aytaç, 2003) and it may lead to a decrease in organizational commitment for employees (Özkul and Çarıkçı, 2010). In the absence of precaution, mobbing can be destructive throughout the organization and lead to a loss of trust within the organization. In addition, a mismatch between employees and administrators and work efficiency decreases (Çobanoğlu, 2005). In other words, it leads to an increase in the inefficiency of the organization and a decrease in the motivation levels of the employees. This has negative consequences for the survival of the organization (Davenport, Distler \& Elliott, 2003).

Thanks to motivation, it is possible to direct the efforts of the employees of the organization in line with the organizational aims. It is up to the motivation levels of the organization members to adopt their work, to be willing and to show enough effort (Fındıkçı, 2009). On this basis, the way organizations motivate employees; may differ according to the management approach of the organization, the environment in which it is located and cultural values. There is no single way to motivate employees. It should be ensured that the motivation technique to be introduced is suitable for the employees. A technique suitable for an employee of an organization may not make sense for another employee. In this case, it is not possible to motivate the employee (Ergül, 2005). It is difficult to motivate employees to mobilize for the benefit of the organization and to keep them in the long run. Creating an environment that will encourage employees to work efficiently, take responsibility, take action to solve problems and reward their success is one of the most important things to be done (Öztürk \& Dündar, 2003). Therefore, employees need effective management in which their needs are met. Managers' level of meeting the needs of employees will affect their commitment to the organization. Employees identified with the organization will be more productive and effective. Such attachment is the fundamental necessity for the organization to achieve its goals and to survive. Managers who take this situation into consideration will ensure that both the needs of the employees are met and the organization achieves its objectives (Ergül, 2005). 


\section{Method}

In this descriptive study, which was designed with a relational scanning model (Mertens, 2010); the relationships between the mobbing behaviors exhibited by school administrators on teachers and teachers' motivation levels were examined according to the views of primary school teachers. In addition, the predictive levels of mobbing behaviors exhibited by school administrators on teachers' motivation levels were examined. The dependent variables of the study are internal and external motivation. The independent variables are the prevention of professional practices, prevention of potential, attacks on a person's reputation, direct insults to the person and prevention of social relations. The population of the study consisted of 673 teachers working in 59 primary schools in Yakutiye district of Erzurum province in the 20182019 academic year, and 217 teachers were the sample. Personal information form developed by the researchers, "Mobbing Scale" developed by Tanhan and Çam (2011) and "Teacher Motivation Scale" developed by Polat (2010) were used as data collection tools. Mean, standard deviation and Pearson Product Moment Correlation Coefficient were used for statistical analysis of the data. In addition, Multiple Linear Regression Analysis was performed to determine the predictive levels of independent variables on dependent variables.

\section{Results}

As a result of the research; the highest level was found in the prevention of professional practices and the lowest level was found in direct insult to the person regarding mobbing dimensions. Taking the teacher motivation scale into consideration, it was found that the highest level was in the intrinsic motivation dimension while the lowest level was in the extrinsic motivation dimension. It was determined that there was a significant relationship between mobbing and motivation levels of teachers. According to the results of the regression analysis, it was found that the sub-dimensions of the mobbing significantly predicted the sub-dimensions of the teacher motivation.

\section{Discussion}

It was found that there is a meaningful relationship between mobbing and teacher motivation levels. It was found that there is a significant negative and high-level relationship between intrinsic motivation and extrinsic motivation and subscales of mobbing scale which are prevention of professional practices, prevention of potential, attacks on a person's reputation, direct insults to the person and prevention of social relations. McKay, Arnold, Fratzl \& Thomas (2008) and McCormack, Casimir, Djurkovic \& Yang (2006) have reached similar results in their research. Mutual interaction is needed to achieve success in organizations. Every administrator is dependent on his or her employees and if they cannot influence them, they are in a difficult situation (Hanks, 1999). A good administrator knows that the authority arising from his personality and, above all, his ability in human relations is far superior to his official power stemming from his position and status (Hagemann, 1997). 